\title{
Coconut Shell Aggregate in Concrete Flooring Tiles
}

\author{
S. Thendral, A. Arunya, R. Chitra
}

\begin{abstract}
The project work report the investigation carried out to determine the use of coconut shell as an aggregate, and the behaviour of coconut shell concrete flooring tiles to comparable to the conventional concrete tiles. The coconut shell flooring tiles were casted and tested as Per IS 1237-1980, the experimental program covers series of physical property tests live texture, size and by tested water absorption, The size of flooring tiles selected for this study was $300 \times 300 \times 20 \mathrm{~mm}$. Totally 12 flooring tiles were casted 6 tiles using conventional flooring tiles and 6 tiles coconut shell flooring tiles. The results indicate the performance of coconut shell flooring tiles was used of coconut shell as an aggregate for the replacement of conventional Marble chips in flooring tile production
\end{abstract}

Keywords - Coconut Shell, Marble chips, Coarse Aggregate.

\section{INTRODUCTION}

A conventional concrete flooring tiles was compared to concrete flooring tiles with coconut shells and fibers of the same proportions. Nowadays most of the researchers have focus on use of the waste Materials in concrete according to their properties. The coconut shell is a material which can be a substitute for coarse aggregate[1]-[5].

\section{A. Scope And Objective}

To study to explore the uses of coconut shell as an aggregate. The performance and the effectiveness of the coconut shell as an aggregate in flooring tiles to be analysis. To findout economical solution of objectives for high construction material the overall objective of the project is to investigate the feasibility of incorporating shell as the replacement of the coarse aggregate in concrete flooring tiles. The experimental program investigation like texture, size and water absorption test. The flooring tile size selected for this study was $300 \times 300 \times 20 \mathrm{~mm}$. Finally to evaluate the overall cost of conventional flooring tiles and coconut shell flooring tiles[6]-[9].

\section{B. Materials And Mix}

The cement used 53 grade of cement. The aggregates used in the base layer of tiles were Quarry dust and specific gravity 2.4. and wearing layer were marble chips and crushed coconut shells used in this study with specific gravity 2.6 and 1.3 .

\section{Mix Proportion}

Revised Manuscript Received on October 22, 2019.

S. Thendral, Department of Civil Engineering, Bharath Institute of Higher Education and Research, Chennai , India. Email: thendral.cs@gmail.com

A. Arunya, Department of Civil Engineering, Bharath Institute of Higher Education and Research, Chennai , India. Email: arunyaaaa@gmail.com

R. Chitra , Department of Civil Engineering, Bharath Institute of Higher Education and Research, Chennai , India Email: chitraroopauma@gmail.com
For the production of flooring tiles, the nominal mix proportion 1:3 (by volume) is selected as per IS 1237: 1980 The same volume batched materials generally used in field practice had been adopted in this study. For the traditional flooring tiles, to prepare the base layer people are using a vessel like a mason bond for taking mix constituents[10]-[15]. They used to take one part of cement and three part of quarry dust for base layer. It was weighed and converted in to mix ratio by weight as 1: 3 and used was 0.40 . The Similarly, for the traditional flooring tiles, to prepare the wearing layer they used to take one part of cement and three parts of marble chips. It was weighed and converted in to mix ratio by weight was 1: 3 and here also the water-cement ratio used was 0.40 coconut shell flooring tiles it was weighed and mix ratio by weight and here also The mix ratios adopted are presented in Table 1 after the conversion of volume batched materials in to weigh batched[16]-[21].
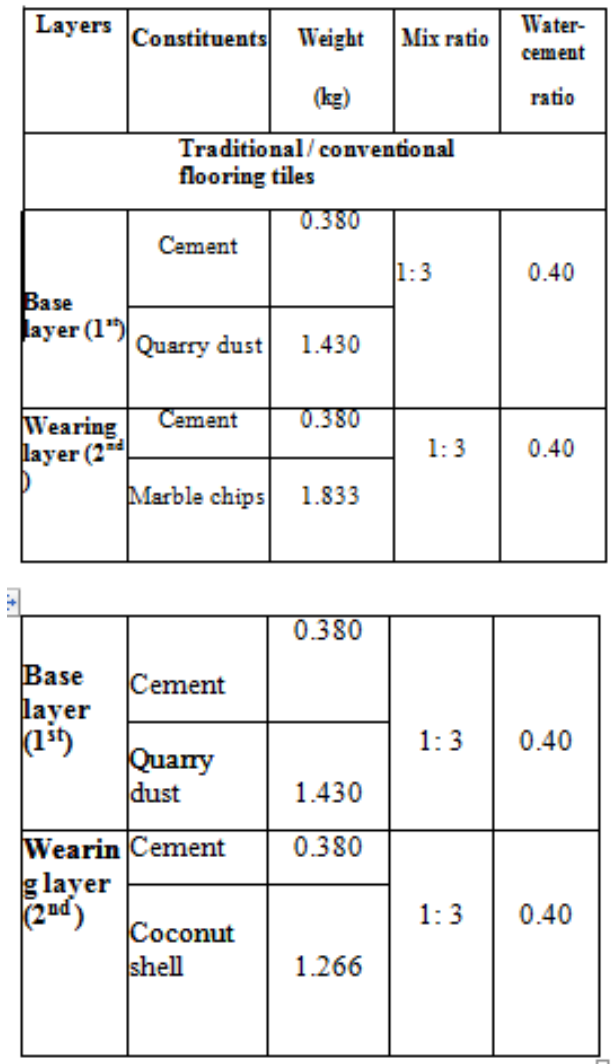

\section{EXPERIMENTAL INVESTIGATION}

\section{A. Casted and Curing of Tiles}

The normal water curing at 28 days both conventional and Coconut shell 


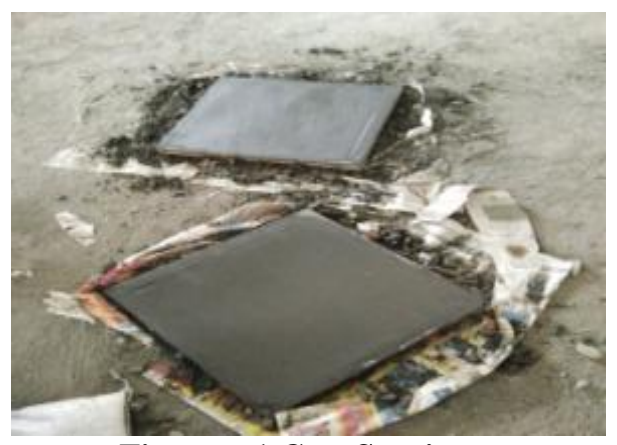

Figure - 1 Cast Specimen

\section{RESULT AND DISCUSSION}

For our investigation both conventional and coconut shell flooring tiles were tested for the parameter as per code is given in the experimental program covers series of physical property tests like texture, size and by tested water absorption, The size of flooring tiles selected for this study was $300 X 300 X 20 \mathrm{~mm}[25]-[28]$. As per code book given there are two types of tiles as well as general purpose and heavy duty purpose of tiles for our investigation general purpose tiles normally used for flooring in such places where normally light loads are taken up by the floors; such as office buildings, schools, colleges, hospitals and residential buildings were selected for this study to compare the conventional concrete flooring tiles the weight of the coconut concrete flooring tiles is very less weight in the structural elements by doing this the self weight of the floor finish may get reduced and hence may lead to economic design of floor supporting structural elements[32]-[34].

\section{CONCLUSION}

The following conclusions can be drawn for this project report

1. Is per IS code book IS 1237-2012, in the purpose of the tiles two types, as well as general purpose and heavy purpose tiles

2. For our investigation both conventional and coconut shell flooring tiles were tested for the parameter as per code is given

3. The water absorption for coconut shell in cycle is less than 65.49 percent resistance with respect to conventional flooring tiles

4. Coconut shell flooring tiles have shown good results compared with conventional flooring tiles in dimensional properties and water absorption test

5. The conventional concrete flooring tiles the weight of the coconut concrete flooring tiles is very less weight, in the structural elements by doing this the self weight of the floor finish may get reduced and hence may lead to economic design of floor supporting structural elements.

\section{REFERENCES}

1. Iyappan L., Dayakar P., Identification of landslide prone zone for coonoortalukusing spatial technology, International Journal of Applied Engineering Research,V-9,I-22,PP-5724-5732,Y-2014.

2. Kumar J., Sathish Kumar K., Dayakar P.,Effect of microsilica on high strength concrete, International Journal of Applied Engineering Research,V-9,I-22,PP-5427-5432,Y-2014.
3. Dayakar P., Vijay Ruthrapathi G., Prakesh J., Management of bio-medical waste, International Journal of Applied Engineering Research,V-9,I-22,PP-5518-5526,Y-2014.

4. Swaminathan N., Dayakar P., Resource optimization in construction project, International Journal of Applied Engineering Research,V-9,I-22,PP-5546-5551,Y-2014.

5. Venkat Raman K., Dayakar P., Raju K.V.B.,An experimental study on effect of cone diameters in penetration test on sandy soil, International Journal of Civil Engineering and Technology,V-8,I-8,PP-1581-1588,Y-2017.

6. Saritha B., Chockalingam M.P.,Photodradation of malachite green DYE using TIO2/activated carbon composite, International Journa of Civil Engineering and Technology,V-8,I-8,PP-156-163,Y-2017

7. Shendge R.B., Chockalingam M.P., Saritha B., Ambica A.,Swat modelling for sediment yield: A case study of Ujjani reservoir in Maharashtra, India,International Journal of Civil Engineering and Technology,V-9,I-1,PP-245-252,Y-2018

8. Chockalingam M.P., Balamurgan V.,Modernisation of an existing urban road-sector in Chennai, a case study report,International Journal of Civil Engineering and Technology,V-8,I-8,PP-1457-1467,Y-2017

9. Saritha B., Chockalingam M.P.,Adsorption study on removal of basic dye by modified coconut shell adsorbent, International Journal of Civil Engineering and Technology,V-8,I-8,PP-1370-1374,Y-2017

10. Saritha B., Chockalingam M.P.,Adsorptive removal of heavy metal chromium from aqueous medium using modified natural adsorbent,International Journal of Civil Engineering and Technology,V-8,I-8,PP-1382-1387,Y-2017

11. Chockalingam M.P., Palanivelraja S.,Retrospective analysis of a theoretical model used for forecasting future air quality near the north Chennai thermal power plant,International Journal of Civil Engineering and Technology,V-8,I-8,PP-1457-1467,Y-2017

12. Saritha B., Chockalingam M.P.,Photodegradation of methylene blue dye in aqueous medium by $\mathrm{Fe}-\mathrm{AC} / \mathrm{TiO} 2$ Composite,Nature Environment and Pollution Technology,V-17,I-4,PP-1259-1265,Y-2018

13. Shendge R.B., Chockalingam M.P., Kaviya B., Ambica A.,Estimates of potential evapotranspiration rates by three methods in upper Bhima Basin, In Maharashtra, India,International Journal of Civil Engineering and Technology,V-9,I-2,PP-475-480,Y-2018 Shendge R.B., Chockalingam M.P.,The soil and water assessment tool for Ujjani Reservoir,International Journal of Mechanical Engineering and Technology,V-9,I-2,PP-354-359,Y-2018

15. Shendge R.B., Chockalingam M.P.,A review on soil and water assessment tool,International Journal of Mechanical Engineering and Technology,V-9,I-2,PP-347-353,Y-2018

16. Sachithanandam P., Meikandaan T.P., Srividya T.,Steel framed multi storey residential building analysis and design,International Journal of Applied Engineering Research,V-9,I-22,PP-5527-5529,Y-2014

17. Meikandaan T.P., Ramachandra Murthy A.,Study of damaged RC beams repaired by bonding of CFRP laminates,International Journal of Civil Engineering and Technology,V-8,I-2,PP-470-486,Y-2017

18. Meikandaan T.P., Ramachandra Murthy A.,Retrofittng of reinforced concrete beams using GFRP overlays, International Journal of Civil Engineering and Technology,V-8,I-2,PP-423-439,Y-2017

19. Meikandaan T.P., Ramachandra Murthy A.,Flexural behaviour of RC beam wrapped with GFRP sheets,International Journal of Civil Engineering and Technology,V-8,I-2,PP-452-469,Y-2017

20. Meikandaan T.P., Murthy A.R.,Experimental study on strengthening of rc beams using glass Fiber,International Journal of Civil Engineering and Technology,V-9,I-11,PP-959-965,Y-2018

21. Meikandaan T.P., Hemapriya M.,Use of glass FRP sheets as external flexural reinforcement in RCC Beam,International Journal of Civil Engineering and Technology,V-8,I-8,PP-1485-1501,Y-2017

22. Saraswathy R., Saritha B.,Planning of integrated satellite township at Thirumazhisai,International Journal of Applied Engineering Research,V-9,I-22,PP-5558-5560,Y-2014 
23. Saritha B., Ilayaraja K., Eqyaabal Z.,Geo textiles and geo synthetics for soil reinforcement,International Journal of Applied Engineering Research,V-9,I-22,PP-5533-5536,Y-2014

24. Ambica A., Saritha B., Changring G., Singh N B., Rajen M., Salman Md.,Analysis of groundwater quality in and around Tambaram taluk, Kancheepuram district,International Journal of Civil Engineering and Technology,V-8,I-8,PP-1362-1369,Y-2017

25. Arunya A., Sarayu K., Ramachandra Murthy A., Iyer N.R.,Enhancement of durability properties of bioconcrete incorporated with nano silica,International Journal of Civil Engineering and Technology,V-8,I-8,PP-1388-1394,Y-2017

26. Ilayaraja K., Krishnamurthy R.R., Jayaprakash M., Velmurugan P.M., Muthuraj S.,Characterization of the 26 December 2004 tsunami deposits in Andaman Islands (Bay of Bengal, India),Environmental Earth Sciences,V-66,I-8,PP-2459-2476,Y-2012

27. Ilayaraja K.,Morphometric parameters of micro watershed in Paravanar sub-basin, Cuddalore District,International Journal of Civil Engineering and Technology,V-8,I-8,PP-1444-1449,Y-2017

28. Ilayaraja K., Singh R.K., Rana N., Chauhan R., Sutradhar N.,Site suitability assessment for residential areas in south Chennai region using remote sensing and GIS techniques,International Journal of Civil Engineering and Technology,V-8,I-8,PP-1468-1475,Y-2017

29. Ilayaraja K., Reza W., Kumar V., Paul S., Chowdhary R.,Estimation of land surface temperature of Chennai metropolitan area using Landsat images,International Journal of Civil Engineering and Technology,V-8,I-8,PP-1450-1456,Y-2017

30. Chitra R.,Experimental study on beam using steel fiber and latex,International Journal of Civil Engineering and Technology,V-8,I-8,PP-1395-1403,Y-2017

31. Chitra R.,Analysis of traffic and management at Kovilambakkam intersection,International Journal of Civil Engineering and Technology,V-8,I-8,PP-1433-1443,Y-2017

32. Aswathy M.,Experimental study on light weight foamed concrete,International Journal of Civil Engineering and Technology,V-8,I-8,PP-1404-1412,Y-2017

33. Aswathy M.,Wastewater treatment using constructed wetland with water lettuce (Eichornia Crasipies),International Journal of Civil Engineering and Technology,V-8,I-8,PP-1413-1421,Y-2017

34. Kiruthiga K., Anandh K.S., Gunasekaran K, Assessment of influencing factors on improving effectiveness and productivity of construction engineers, 2015, International Journal of Applied Engineering Research, V - 10,I -17,p -13849-13854.

\section{AUTHORS PROFILE}

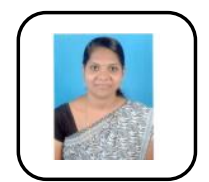

S. Thendral Assistant Professor, Department of Civil Engineering, Bharath Institute of Higher Education and Research, Chennai, India.

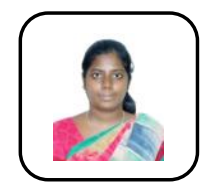

A. Arunya Assistant Professor, Department of Civil Engineering, Bharath Institute of Higher Education and Research, Chennai, India.

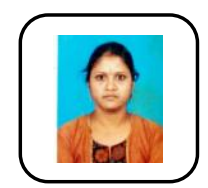

R. Chitra Assistant Professor, Department of Civil Engineering, Bharath Institute of Higher Education and Research, Chennai, India. 